\title{
Screening the protective effect of aqueous leaf extract of Hibiscus rosa-sinensis L. against phenytoin induced cognitive impairment in mice
}

\author{
Syed Ahmedullah Hussaini Quadri*, Maya Sharma, Khaja Pasha* and Javed Akhtar Ansari** \\ Department of Pharmaceutical Sciences, Faculty of Pharmacy, PAHER University, Udaipur-313001, Rajasthan, India \\ * Department of Pharmaceutical Analysis, Azad College of Pharmacy, Hyderabad-500075, Telangana State, India \\ ** Department of Pharmacology, MESCO College of Pharmacy, Karwan-500006, Hyderabad, Telangana State, India
}

\section{Article Info}

Article history

Received 3 August 2021

Revised 20 September 2021

Accepted 21 September 2021

Published Online 30 December 2021

\section{Keywords}

Phenytoin

Cooks pole climbing test

Novel object recognition test

Biochemical estimations

Histopathological study

\begin{abstract}
Neurological disorders like Alzheimer's disease, dementia and parkinsonism are associated cognitive impairment. This study aims to evaluate the protective effect of aqueous extract of Hibiscus rosasinensis L. (HRWE) leaves against phenytoin induced cognitive impairment in mice. Phenytoin chronic treatment $(50 \mathrm{mg} / \mathrm{kg})$ for 10 days successfully induced learning and memory impairment in animals. HRWE showed antioxidant effects in hydroxyl radical scavenging assay and hydrogen peroxide scavenging assay. Ascorbic acid was used as standard for these assays. $\mathrm{IC}_{50}$ values are found to be $470 \mu \mathrm{g} / \mathrm{ml}$ and $450 \mu \mathrm{g} /$ $\mathrm{ml}$ for $\mathrm{H}_{2} \mathrm{O}_{2}$ and hydroxyl radical scavenging assay, respectively. Cognition function of animals is assessed by using common behavioural animal models like morris water maze test (MWM), elevated plus maze test (EPM), cooks pole climbing test (CPC), novel object recognition test (NOR), rotarod test (RTR) and rod walking test (RDW). In all these behavioural models, control group animals showed reduced learning and defective memory indicated by, increase in reaction time, escape and transfer latency, and decrease in recognition index, fall off time and inflexion ratio. However, piracetam (standard drug) and HRWE treatment showed significant decrease in reaction time, escape and transfer latency and significant increase in recognition index, fall off time and inflexion ratio; this restoration indicates effective memory and improved learning behavior. At the end of study, brain homogenates are used to conduct biochemical estimations. Increase in levels of acetylcholinesterase (AChE), lipid peroxidase (LPO) and nitric oxide (NO), and decrease in levels of glutathione (GSH) and superoxide dismutase (SOD) in control group animals shows oxidative stress produced on phenytoin challenge. Piracetam is found to be most effective in restoring these enzymes to normal values. However, HRWE $100 \mathrm{mg} / \mathrm{kg}$ showed significant effects only in restoration of AChE, LPO and NO levels. In contrast, HRWE $200 \mathrm{mg} / \mathrm{kg}$ showed significant restoration of all biochemical enzymes as compared to control group. Important to state that the HRWE effect is less significant than the effect produced by piracetam. Histopathological studies are also conducted to explore morphological changes in brain samples of all the treatments. Apoptosis of neurons in control group animals' correlates to their abnormal behaviour in study. Whereas, normal histoarchitecture of brain examination of piracetam and HRWE treated animals, extrapolates to their cognitive improved behavior in study. All these results justify the protective effect of water extract of HRWE against phenytoin induced cognitive disabilities.
\end{abstract}

\section{Introduction}

Phenytoin is a commonly used antiepileptic drug. Even though, it is recognized for beneficial concepts, but it is also noted to induce impairment of cognitive functions. Disturbed memory, impaired learning, altered psychomotor functions are some of the adverse effects of phenytoin. These are produced at both lower and higher doses of phenytoin (Vohora et al., 2000; Sudha et al., 1995). Cognitive impairment is the major symptom of many degenerative brain diseases like, Alzheimer's disease, dementia, Huntington's disease, Parkinson's disease, multiple sclerosis. All these diseases have a vital impact on moral, financial and social life of not only patients but also family

Corresponding author: Mr. Syed Ahmedullah Hussaini Quadri Department of Pharmaceutical Sciences, Faculty of Pharmacy, PAHER University, Udaipur-313001, Rajasthan, India

E-mail: sah296@gmail.com

Tel.: +91-7386967786; 9100776347

Copyright () 2021 Ukaaz Publications. All rights reserved.

Email: ukaaz@yahoo.com; Website: www.ukaazpublications.com
(Domaradzki, 2015; Lauterbach et al., 2010). Not only in the disease conditions, cognitive impairment also occurs in aged people. Normally as the individual grows older except few most of the cognitive functions decline (Hazzard, 2009). Therefore, it is an important behaviour of life that has to be controlled. In general, cholinergic drugs are used to alleviate these cognitive problems (Mangialasche, 2010). These drugs usually act by inhibiting AChE enzymes. Many other plants are also explored for this AChE inhibitory activity (Abubucker, 2021). However, effects on cognitive improvement are very mild. As these drugs have short half-life, frequent usage is the major challenge for the patients (Polinsky, 1998). Along with this, usage of cholinergic drugs is also associated with renal failure, vomiting, etc. (Rogers, 1998). Another important drug usually studied for this purpose is piracetam (Moran, et al., 2002). Piracetam is a nootropic drug, usually act by enhancing cholinergic neurotransmission (Wurtman et al., 1981). However, frequent use of piracetam results in dysphoria, amnesia, and psychomotor agitation (Talih and Ajaltouni, 2015). Hence, there is a need of safe and effective 
drugs which can reverse cognitive abnormalities. Since last few decades, plant-based drugs are gaining popularity in treatment of many life-threatening conditions like cancer, diabetes, neurological disease.

H. rosa-sinensis (HRWE) is one of the well-known medicinal plants. It is commonly called as queen of tropics. This plant belongs to family of flowers called as Malvaceae (Braglia et al., 2010). Every part of the plant is reported to possess therapeutic activity. Antiinflammatory (Raduan et al., 2013), antimicrobial (Nayak et al., 2015), antitumour (Goldberg et al., 2017), antioxidant (Masaki et al., 1995), antidepressant (Khalid et al., 2014), antidiabetic (Afiune et al., 2017) are the few important medicinal uses of flowers of HRWE. Leaves and roots are reported to have antibacterial, antifungal (Hemarana et al., 2014; Sobhy et al., 2017), antidiabetic (Moqbel et al., 2011; Kumar et al., 2013), antipyretic (Soni and Gupta, 2011; Daud et al., 2016) activities. Apart from these, HRWE is also reported for many other activities. All these activities are due to different phytoconstituents like quercetin, quercetin-3-diglucoside, $\beta$ sitosterol, cyanidin-3,5-diglucoside (Jadhav et al., 2009), cyanidin3-sophoroside (Senathirajah et al., 2017), luteolin-8-C-glucoside (Zaki et al., 2017). Flowers and roots of the plant are also reported for neuroprotective activity (Hanumakonda and Maheshwaram, 2016; Begum et al., 2016). Scientists now-a-days are focusing towards development of plant-based treatment of neurodegenerative diseases (Imad et al., 2020; Abdulrahman, 2019). Use of plant-based medicines is not only effective but also safe. Many drugs in market are derived from plant extracts. Therefore, present study is designed to evaluate protective effect of water extract of leaves of HRWE against phenytoin induced cognitive impairment in mice.

\section{Materials and Methods}

\subsection{Chemicals required for study}

Chemicals procured for the study are analytical grade. Piracetam and phenytoin are obtained from Dr. Reddy's Labs, Hyderabad and Abbott Healthcare Pvt. Ltd., Hyderabad, respectively. Acetyl acetone, ammonium acetate, $\mathrm{K}_{2} \mathrm{HPO}_{4}$, DMSO, ferrous ammonium sulphate, glacial acetic acid, $\mathrm{H}_{2} \mathrm{O}_{2} \mathrm{NADPH}$, and $\mathrm{KCl}$, are procured from SDFCL Pvt. Ltd., Hyderabad. Other chemicals used in the study are procured as follows, hydroxylamine hydrochloride (Accord Labs, Hyderabad), EDTA (Essel Fine Chemicals), ascorbic acid, $\mathrm{KH}_{2} \mathrm{PO}_{4}$, TCA (Finar Chemicals), acetylthiocholine, DTNB, nitroblutetrazolin (SRL Pvt. Ltd., Hyderabad).

2.2 Selection, extraction and antioxidant activity of $\boldsymbol{H}$. rosasinensis

HRWE leaves are collected in the month of January 2021. Mainly, the plants located in Hyderabad are selected for the study. This plant is subjected to authentication at Botanical Survey of India and a specimen (MESCO/PCOG/2020/046) is deposited in Department of Pharmacognosy, MESCO College of Pharmacy. These leaves are washed under running water to remove dirt and waste, dried in shade for around 8 days. These leaves after grinding to coarse powder, subjected to water extraction by using Soxhlet extractor. This process of extraction was continued for about 1 week to get sufficient amount of extract. This is subjected to in vitro antioxidant activity by using hydroxyl radical scavenging assay and $\mathrm{H}_{2} \mathrm{O}_{2}$ radical scavenging assay. In hydroxyl radical scavenging assay, test tubes containing $0.5 \mathrm{ml}$ of $0.018 \%$ EDTA, $0.1 \mathrm{ml}$ of iron-EDTA solution, $0.1 \mathrm{ml}$ of $0.85 \%$ DMSO solution and $0.1 \mathrm{ml}$ of HRWE (100 - $500 \mu \mathrm{g} / \mathrm{ml})$ add $0.5 \mathrm{ml}$ of $0.22 \%$ ascorbic acid. Contents are mixed and incubated at $80^{\circ} \mathrm{C}$, to this add $0.1 \mathrm{ml}$ of $17.5 \% \mathrm{TCA}$, and $3 \mathrm{ml}$ of NASH reagent. Finally, contents are incubated for $15 \mathrm{~min}$ for the development of yellow color which is measured at $412 \mathrm{~nm}$ (UV-Visible spectrophotometer) Klein et al. (1981). Whereas, in $\mathrm{H}_{2} \mathrm{O}_{2}$ assay, to the test tubes containing $0.1 \mathrm{ml}$ of HRWE (100 - $500 \mu \mathrm{g} / \mathrm{ml}$ ) add $0.4 \mathrm{ml}$ of $\mathrm{pH} 7.4,50 \mathrm{mM}$ phosphate buffer was added. After adding $0.6 \mathrm{ml}$ of $2 \mathrm{~m} \mathrm{M} \mathrm{H}_{2} \mathrm{O}_{2}$ solution' mix it for $15 \mathrm{~min}$ and record absorbance at $230 \mathrm{~nm}$ (Ruch et al., 1989; Bhatti et al., 2015). For both assays, ascorbic acid was used as standard and \% inhibition was calculated by using the formula:

$\%$ inhibition $=\left[\left(\mathrm{A}_{0}-\mathrm{A}_{1}\right) / \mathrm{A}_{0}\right] \times 100$. where: $\mathrm{A}_{0}=$ Control absorbance, $\mathrm{A}_{1}=$ Sample absorbance.

2.3 Methods used for screening protective effect of HRWE against phenytoin induced cognitive impairment

\subsubsection{Selection of animals, toxicity studies and grouping}

Animal studies are approved by IAEC of Deccan School of Pharmacy (1773/PO/Re/S/14/CPCSEA). Acute toxicity study is conducted on swiss albino mice by using OECD-425 guidelines. After selection of dose, animal grouping is done for main study. Around 25 swiss albino mice of both sexes are selected and divided in to 5 groups with 5 animals in each. Animals receiving only vehicle considered as normal group (Group I), other groups (Groups II to V) received phenytoin $50 \mathrm{mg} / \mathrm{kg}$, i.p for 10 days to induce cognitive impairment (Sudha et al., 1995). Animals receiving phenytoin and vehicle served as control group (Group II), whereas, animals receiving piracetam $(100 \mathrm{mg} / \mathrm{kg}$, i.p), HRWE $100 \mathrm{mg} / \mathrm{kg}$, p.o. and HRWE $200 \mathrm{mg} / \mathrm{kg}$ p.o. are considered as Groups III, IV and V, respectively.

\subsubsection{Effect of HRWE on behavioral studies}

To screen the cognitive improvement effect of HRWE, different models are used, viz., MWM test, EPM test, CPC test, NOR test, RTR test, and RDW test. Before screening, all the animals are trained for 2 days. Readings are taken on $0^{\text {th }}$ day, $1^{\text {st }}$ day $5^{\text {th }}$ day, and $10^{\text {th }}$ day.

In MWM test, a plastic water tank is used which is divided in to 4 quadrants, viz., north, south, east and west. It is about $80 \mathrm{~cm} \mathrm{X} 40$ $\mathrm{cm}$, with a central platform of $6 \mathrm{~cm} \mathrm{X} 15 \mathrm{~cm}$. Water $\left(25^{\circ} \mathrm{C}\right)$ is filled in the tank such that it is $1.5 \mathrm{~cm}$ above the platform and it is made opaque by adding non-toxic color. Experimental room is provided with external clues. Animal is placed at the fixed starting point and time taken to find the hidden platform is recorded as "escape latency" (Morris, 1981). Whereas, in EPM test, transfer latency (TL) is calculated. This maze (height $=25 \mathrm{~cm}$ from floor) has 2 open and 2 closed arms. Open and closed arms have dimensions like $25 \mathrm{~cm}$ X 5 $\mathrm{cm}$ and $25 \mathrm{~cm} \times 5 \mathrm{~cm}$ X $20 \mathrm{~cm}$, respectively. By keeping the animal on central platform $(5 \mathrm{~cm} \mathrm{X} 5 \mathrm{~cm})$, time to taken to enter closed arm is recorded as TL. Total duration of experiment is about $2 \mathrm{~min}$. Inflexion ratio (IR) is calculated as $\mathrm{IR}=\left(\mathrm{L}_{1}-\mathrm{L}_{0}\right) / \mathrm{L}_{0}$. where $\mathrm{L}_{0}=\mathrm{TL}$ after $\mathrm{n}^{\text {th }}$ day and $\mathrm{L}_{1}=$ initial TL(s) (Jaiswal and Bhattacharya, 1992; Dhingra et al., 2012). In pole climbing test, equipment consists of iron grid platform, a central wooden pole. A conditioned and an unconditioned stimulus is provided to animal kept on the grid. A 50 $\mathrm{Hz}$ buzzer sound act as conditioned, whereas $1 \mathrm{~mA}$ shock applied through grid function as unconditioned stimulus. Endpoint of procedure is the ability of an animal to jump on pole after buzzer sound or maximum of $30 \mathrm{sec}$ after giving foot sock. Time taken by an 
animal to give this endpoint is recorded as reaction time (RT) (Hanumakonda and Maheshwaram, 2016; Kumar and Minshu, 2016).

In NOR test, open field of dimensions about $40 \mathrm{~cm} \mathrm{X} 40 \mathrm{~cm}$ X $30 \mathrm{~cm}$ is used. On all sides, field is provided with walls of height $40 \mathrm{~cm}$ during training period animal is allowed to explore the field with two similar objects for $5 \mathrm{~min}$ on the day of experiment. This is repeated, later on, one old object is replaced with the new object. Time spent by animal near to old (TO) and new (TN) is recorded. Recognition index $(\mathrm{RI})$ is calculated as $\mathrm{RI}=\mathrm{TN} /(\mathrm{TO}+\mathrm{TN}) * 100$ ] where $\mathrm{TO}$ is time spent exploring old object and TN is time spent exploring new object (Batool et al., 2016; Antunes and Biala, 2012; Ennaceur and Delacour, 1988). In RTR test, multi compartment apparatus is used. Rod is allowed to rotate on a fixed speed of about $20-25 \mathrm{rpm}$, and time taken by the animal to fall off from rod is recorded (Kuribara $e t$ al., 1977). Whereas, in RDW test, ability of an animal to walk on a horizontal stationary rod is recorded. Rod is placed $23 \mathrm{~cm}$ above the floor and about $100 \mathrm{~cm}$ long and $5 \mathrm{~mm}$ in diameter. After placing animal at the center, time taken by the animal to reach the end of rod is recorded as TL (Kamila et al., 2014).

\subsubsection{Effect of HRWE on biochemical parameters histopatho- logical studies}

At the end of study, on the $11^{\text {th }}$ day, all animals are sacrificed and brain isolated. $0.1 \mathrm{M}, \mathrm{pH} 7.4$ cold phosphate buffer is used to make $10 \% \mathrm{w} / \mathrm{v}$ brain homogenate. This homogenate is used for biochemical estimations. For determination of AChE activity, test tube containing $0.1 \mathrm{ml}$ of $1 \mathrm{mM}$ DTNB, $2.6 \mathrm{ml}$ of $0.1 \mathrm{M}$ phosphate buffer $\mathrm{pH} 8.0$ and $0.4 \mathrm{ml}$ of brain homogenate is mixed thoroughly. Endpoint of reaction is the formation of yellow color compound whose absorbance is measured at $412 \mathrm{~nm}$. After recording basal reading (initial stable value) $20 \mu \mathrm{l}$ of $0.075 \mathrm{M}$ acetylthiocholine is added to above mixture and incubated for $5 \mathrm{~min}$. Final change in absorbance is recorded (Ellman et al., 1961). AChE activity was calculated as follows: $\mathrm{R}=$ $5.74 \times 10^{-4} \times$ " $\mathrm{A} / \mathrm{CO}$; where, $\mathrm{R}=$ Rate in moles of substrate hydrolyzed/ $\mathrm{min} / \mathrm{mg}$ of tissue, "A = Change in absorbance, $\mathrm{CO}=$ Original concentration of the tissue $(\mathrm{mg} / \mathrm{ml})$. Obtained $\mathrm{R}$ value is in mole which is converted to $\mu \mathrm{M}$ by multiplying with $10^{6}$. Finally, AChE activity is expressed as $\mu \mathrm{M}$ of acetylthiocholine hydrolyzed $/ \mathrm{min} /$ mg of tissue (Davies and Maloney, 1976; Appleyard, 1992). Whereas, for determination of amount of malondialdehyde (MDA/TBARS) in brain homogenate, $0.5 \mathrm{ml}$ of $30 \%$ trichloroacetic acid and $0.5 \mathrm{ml}$ of $0.8 \%$ thiobarbituric acid is taken in a test tube. To this, add $1 \mathrm{ml}$ of brain homogenate and incubate for $1 \mathrm{~h}$ at $80^{\circ} \mathrm{C}$ on water bath. Later on, it is allowed to cool down for $30 \mathrm{~min}$. Mixture is centrifuged for $15 \mathrm{~min}$ at $3000 \mathrm{rpm}$ and supernatant is collected. End product of reaction is the formation of pink color compound whose intensity is measured at $540 \mathrm{~nm}$. Blank solution consists of $1 \mathrm{ml}$ of distilled water in place of brain homogenate (Okhawa et al., 1979). Nanomole of MDA $/ \mathrm{mg}$ protein is calculated as $\frac{\text { Nanomole of MDA }}{\mathrm{mg} \text { protein }}=$ $\left(\frac{\mathrm{V} \times \mathrm{OD}_{540}}{0.156}\right) \times \mathrm{mg}$ of protein where, $\mathrm{V}=$ Final volume of the test solution; OD $=$ Optical density at $540 \mathrm{~nm}$.

For determination of GSH, $900 \mu \mathrm{l}$ of $20 \mathrm{mM}$, pH 4.7 EDTA solution, $1000 \mu \mathrm{l}$ of $0.2 \mathrm{M}, \mathrm{pH} 8.2$ tris-EDTA buffer is taken in a test tube.
Test tubes are incubated for $30 \mathrm{~min}$ at room temperature after adding $100 \mu \mathrm{l}$ of brain homogenate or pure GSH and $20 \mu \mathrm{l}$ of Ellman's reagent (10 $\mathrm{mmol} / \mathrm{l} \mathrm{DTNB}$ in methanol). Endpoint of reaction is the formation of yellow colored compound, 5- thionitrobenzoic acid (TNB). Supernatant is collected after centrifugation and absorbance is recorded at $412 \mathrm{~nm}$. Absorbance reading is used to calculate nanomole of GSH present in mg of protein (Sedlak and Lindsay, 1968; Khynriam and Prasad, 2003).

$$
\frac{\text { Nanomole of GSH }}{\mathrm{mg} \text { protein }}=\left(\frac{\text { Dilution factor } \times \mathrm{OD}_{412}}{1.36 \times 10^{4}}\right) \times 100 \text {. }
$$

Formula used is where $1.36 \times 10^{4}=$ Extinction coefficient; dilution factor $=10$. For determination of SOD, $1.06 \%$ of $1 \mathrm{ml}$ of sodium carbonate solution, $0.4 \mathrm{ml}$ of $24 \mathrm{mmol} / 1$ of nitro blue tetrazolium, 0.2 $\mathrm{ml}$ of $0.37 \%$ of EDTA and $0.1 \mathrm{ml}$ of brain homogenate is taken in a test tube. 0 min absorbance is taken at $560 \mathrm{~nm}$. After adding $0.4 \mathrm{ml}$ of $1 \mathrm{mM}$ hydroxylamine hydrochloride above mixture is incubated at $25^{\circ} \mathrm{C}$ for $5 \mathrm{~min}$ and final absorbance is recorded (Misra and Fridovich, 1972). \% Inhibition of NBT reduction by SOD is calculated as $\%$ inhibition of NBT reduction by SOD $=\left(\frac{\text { Control OD }- \text { Treatment OD }}{\text { Control OD }}\right)$ $100=\mathrm{X} \%$ inhibition $50 \%$ inhibition is equal to 1 unit of enzyme then $\mathrm{X} \%=\left(\frac{1}{50}\right) \mathrm{X}=\mathrm{Y}$ Unit. NO levels in brain tissue are calculated by using standard curve of sodium nitrite (Figure 1). Reaction mixture consists of $1.5 \mathrm{ml}$ of griess reagent and $0.3 \mathrm{ml}$ of brain homogenate. Absorbance of above mixture is recorded at $546 \mathrm{~nm}$ and NO level is calculated as $\mathrm{ng} / \mathrm{mg}$ of protein. For histopathological studies, brain of one animal from each group is fixed in $10 \%$ formalin. Morphological observation is conducted by using brain sections of 5 $\mu \mathrm{m}$ thickness. Staining process is carried out by using hematoxylin and eosin dye.

\subsubsection{Statistical analysis}

All the values are represented as mean \pm SEM. Analysis is carried out by using one-way ANOVA followed by Dunnett's multiple comparison test in Graph pad prism 9.0 software. * $=p<0.05$; ** $=$ $p<0.01 ; * * *=p<0.001 ; * * * *=p<0.0001$ and $p<0.05 \mathrm{~ns}=$ nonsignificant.

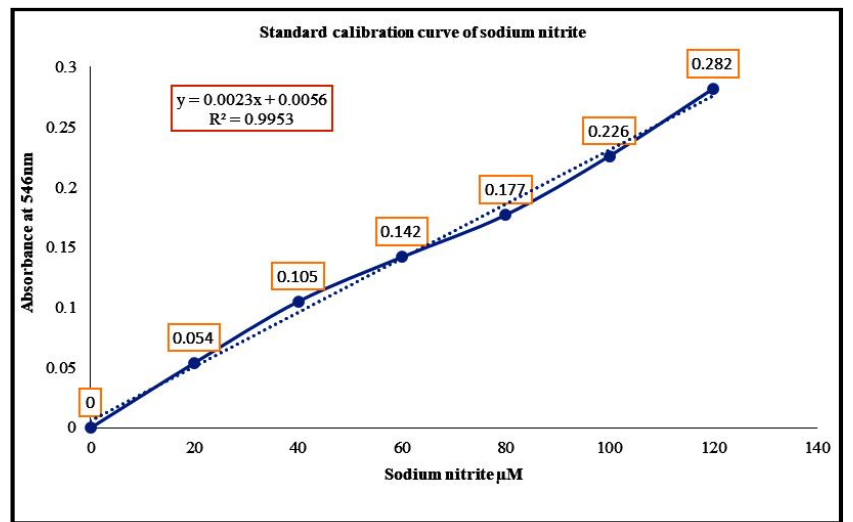

Figure 1: Concentration of sodium nitrite in $\mu \mathrm{M}$ is plotted on $\mathrm{X}$-axis and its absorbance at $546 \mathrm{~nm}$ is plotted on $\mathrm{Y}$ axis to obtain calibration graph of sodium nitrite. 


\section{Results}

3.1 Plant extraction and effect of HRWE on in vitro antioxidant activity and toxicity studies

Extraction of leaves of HRWE yielded dark coloured semisolid extract with a percentage yield of $11.5 \%$. Scavenging activity of HRWE in both $\mathrm{H}_{2} \mathrm{O}_{2}$ and hydroxyl radical scavenging assay increased from 100 $\mu \mathrm{g} / \mathrm{ml}$ to $500 \mu \mathrm{g} / \mathrm{ml}$. IC ${ }_{50}$ values are found to be $470 \mu \mathrm{g} / \mathrm{ml}$ and 450 $\mu \mathrm{g} / \mathrm{ml}$ for $\mathrm{H}_{2} \mathrm{O}_{2}$ and hydroxyl radical scavenging assay, respectively. HRWE in both assays is less potent than standard ascorbic acid. $\mathrm{IC}_{50}$ values are found to be $200 \mu \mathrm{g} / \mathrm{ml}$ and $90 \mu \mathrm{g} / \mathrm{ml}$ for $\mathrm{H}_{2} \mathrm{O}_{2}$ and hydroxyl radical scavenging assay, respectively (Figure 2). In acute toxicity studies, no mice showed signs of toxicity throughout the study duration at $2000 \mathrm{mg} / \mathrm{kg}$. Therefore, very low doses $1 / 20^{\text {th }}$ and $1 / 10^{\text {th }}$, i.e., $100 \mathrm{mg} / \mathrm{kg}$ and $200 \mathrm{mg} / \mathrm{kg}$ are selected for the study, respectively.

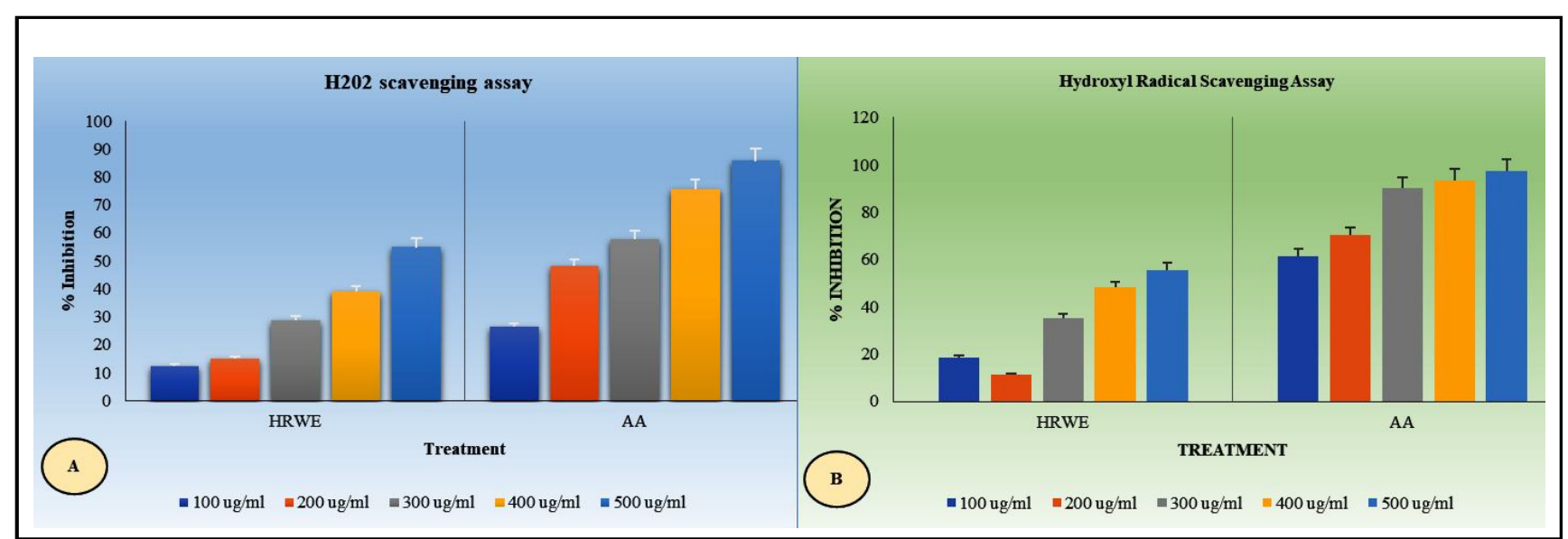

Figure 2: In vitro antioxidant activity of $\mathrm{HRWE}$ by using ascorbic acid as standard. $\mathrm{A}_{2} \mathrm{H}_{2} \mathrm{O}_{2}$ scavenging assay, $\mathrm{B}$ : $\mathrm{Hydroxyl}$ radical scavenging assay.

\subsection{Effect of HRWE on in vivo cognitive improvement activity}

In MWM test, escape latency was found to increase in control group animals from day $1(p<0.0001)$ to day $10(p<0.0001)$ as compared to normal group. In piracetam treated animals, escape latency decreases from day $1(p<0.0001)$ to day $10(\mathrm{p}<0.0001)$ as compared to control group. HRWE $100 \mathrm{mg} / \mathrm{kg}$ has not showed any significant effect, but HRWE $200 \mathrm{mg} / \mathrm{kg}$ has showed significant decrease in escape latency from day $1(p<0.05)$ to day $10(p<0.0001)$ as compared to control group. In EPM test, IR decreased from day 1 to day 10 as compared to normal group. Animals treated with piracetam showed significant increase in IR from day $1(p<0.01)$ to day 10 $(p<0.001)$ as compared to control group. Whereas, animals treated with both doses of HRWE has not showed significant increase in IR as compared to control group. RT in seconds is recorded in CPC test. RT significantly increased in control group animals from day 5 $(p<0.001)$ to day $10(p<0.0001)$. In piracetam treated group RT significantly decreased from day $1(p<0.001)$ to day $10(p<0.0001)$ as compared to control group. HRWE $100 \mathrm{mg} / \mathrm{kg}$ showed decrease in RT from day 1 to day 10, but changes are not significant. However, HRWE $200 \mathrm{mg} / \mathrm{kg}$ showed significant decrease in RT from day 1 $(p<0.01)$ to day $10(p<0.001)$ as compared to control group. In NOR test, RI significantly decreased in control group animals from day 1 $(p<0.05)$ to day $10(0.0001)$. Piracetam group showed significant increase in RI from day $1(p<0.01)$ to day $10(p<0.0001)$ as compared to control group. HRWE $100 \mathrm{mg} / \mathrm{kg}$ and $200 \mathrm{mg} / \mathrm{kg}$ showed significant increase in RI only on day $10(p<0.001)$ as compared to control group (Table 1).

Table 1: Effect of HRWE on escape latency (MWM test), inflexion ratio (EPM test), reaction time (CPC test), and recognition index (NOR test).

\begin{tabular}{|c|c|c|c|c|}
\hline Treatment & Day 0 & Day 1 & Day 5 & Day 10 \\
\hline \multicolumn{5}{|c|}{ Escape latency in sec (Morris water maze test) } \\
\hline Normal & $60 \pm 1.9^{\mathrm{ns}}$ & $32 \pm 2.2 * * * *$ & $24 \pm 1.9 * * * *$ & $19 \pm 1.5^{* * * *}$ \\
\hline Control & $63 \pm 1.9$ & $53 \pm 1.5$ & $49 \pm 1.7$ & $45 \pm 1.7$ \\
\hline Piracetam $100 \mathrm{mg} / \mathrm{kg}$ & $65 \pm 1.4^{\text {ns }}$ & $41 \pm 0.98 * * *$ & $35 \pm 1.3 * * * *$ & $27 \pm 1.2 * * * *$ \\
\hline HRWE $100 \mathrm{mg} / \mathrm{kg}$ & $60 \pm 0.93$ ns & $55 \pm 1.2^{\mathrm{ns}}$ & $45 \pm 1.5^{\mathrm{ns}}$ & $39 \pm 0.89^{\text {ns }}$ \\
\hline HRWE $200 \mathrm{mg} / \mathrm{kg}$ & $60 \pm 1.50^{\mathrm{ns}}$ & $46 \pm 1.8 *$ & $37 \pm 2.3 * * *$ & $31 \pm 2.4 * * * *$ \\
\hline \multicolumn{5}{|c|}{ Inflexion ratio (Elevated plus maze test) } \\
\hline Normal & -- & $0.084 \pm 0.034^{\mathrm{ns}}$ & $0.21 \pm 0.061^{\mathrm{ns}}$ & $0.1 \pm 0.043^{\mathrm{ns}}$ \\
\hline Control & -- & $-0.36 \pm 0.07$ & $-0.42 \pm 0.077$ & $-0.53 \pm 0.04$ \\
\hline Piracetam $100 \mathrm{mg} / \mathrm{kg}$ & -- & $1.1 \pm 0.52 * *$ & $1 \pm 0.39 * *$ & $1.7 \pm 0.5^{* * *}$ \\
\hline HRWE $100 \mathrm{mg} / \mathrm{kg}$ & -- & $0.24 \pm 0.12^{\mathrm{ns}}$ & $0.14 \pm 0.16^{\mathrm{ns}}$ & $0.22 \pm 0.097^{\mathrm{ns}}$ \\
\hline HRWE 200 mg/kg & -- & $0.25 \pm 0.037^{\mathrm{ns}}$ & $0.56 \pm 0.39 *$ & $0.16 \pm 0.067^{\mathrm{ns}}$ \\
\hline
\end{tabular}


Reaction time in sec (Cooks pole climbing test)

\begin{tabular}{l|l|l|l|l}
\hline Normal & $77 \pm 2.5^{\text {ns }}$ & $59 \pm 1.6^{\text {ns }}$ & $32 \pm 2.6^{* * *}$ & $16 \pm 1.4^{* * * *}$ \\
Control & $77 \pm 1.8$ & $69 \pm 1.6$ & $60 \pm 1.8$ & $45 \pm 1.8$ \\
Piracetam $100 \mathbf{~ m g / k g}$ & $79 \pm 2.6^{\mathrm{ns}}$ & $51 \pm 2.8^{* * *}$ & $34 \pm 3.8^{* * *}$ & $18 \pm 2.5^{* * * *}$ \\
HRWE $100 \mathrm{mg} / \mathrm{kg}$ & $76 \pm 1.8^{\mathrm{ns}}$ & $63 \pm 3.2^{\mathrm{ns}}$ & $52 \pm 1.7^{\mathrm{ns}}$ & $40 \pm 2.6^{\mathrm{ns}}$ \\
HRWE $200 \mathrm{mg} / \mathrm{kg}$ & $76 \pm 1.9^{\mathrm{ns}}$ & $54 \pm 3.9^{* *}$ & $40 \pm 2.7^{* * * *}$ & $30 \pm 1.6^{* * *}$ \\
\hline
\end{tabular}

All values are expressed as mean $\pm \mathrm{SEM}$, and tested by One-way ANOVA followed by Dunnett's multiple comparison test, $\mathrm{n}=5$, $*=p<0.05 ; * *=$ $p<0.01 ; * * *=p<0.001 ; * * * *=p<0.0001$ and $\mathrm{ns}=$ non-significant as compared to control group.

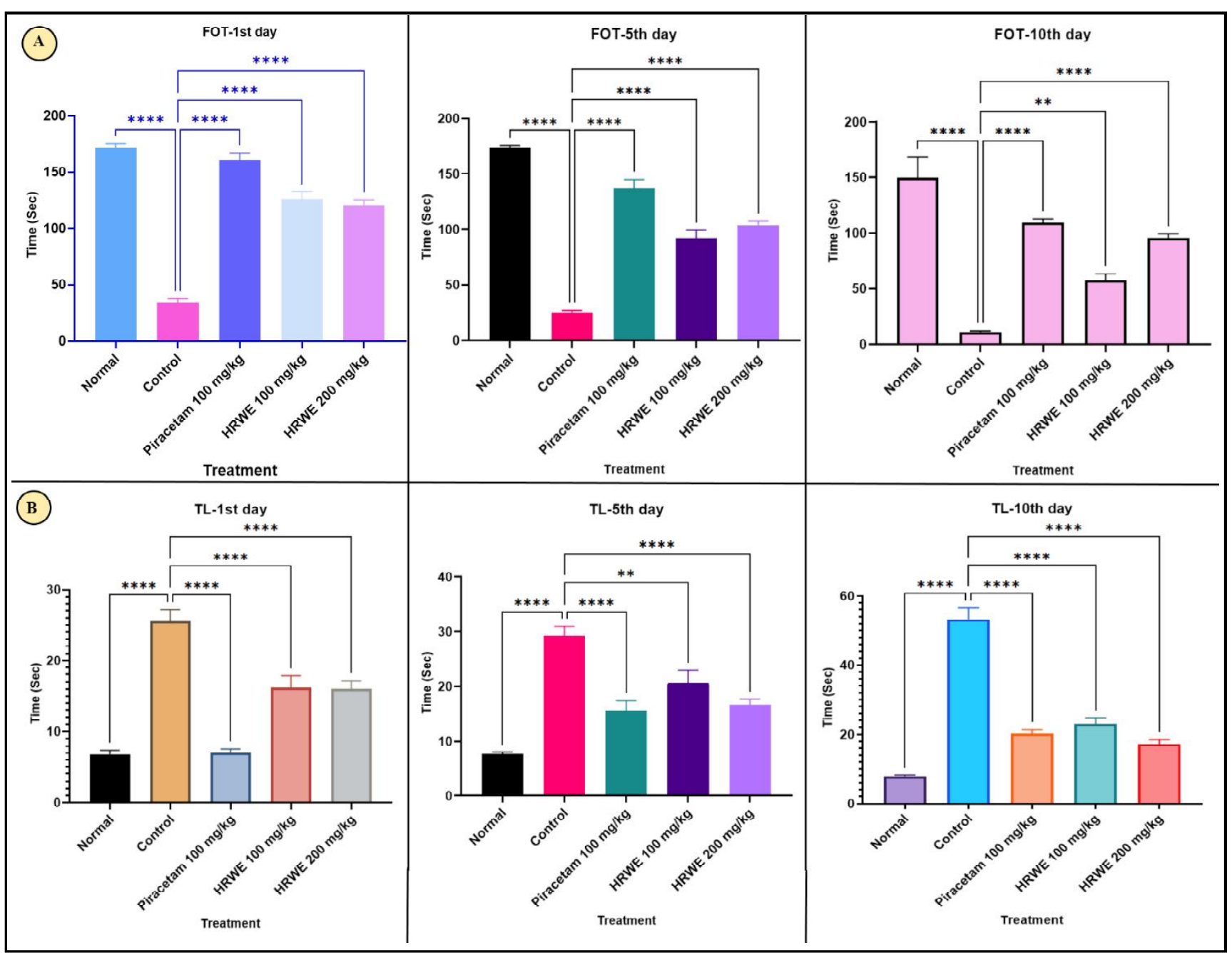

Figure 3: Effect of HRWE on fall off time (FOT) recorded in RTR test and transfer latency recorded in RDW test. All values are expressed as mean \pm SEM, and tested by One-way ANOVA followed by Dunnett's multiple comparison test, $n=5, *=$ $p<0.05 ; * *=p<0.01 ; * * *=p<0.001 ; * * * *=p<0.0001$ and $\mathrm{ns}=$ non-significant as compared to control group. 
In RTR test, fall off time significantly decreased in control group from day $1(p<0.0001)$ to day $10(p<0.0001)$. Fall off time significantly increased in all the treatment groups as compared to control group from day $1(p<0.0001)$ to day $10(p<0.0001)$ as compared to control group. Effect is more significant in HRWE 200 $\mathrm{mg} / \mathrm{kg}$ when compared to HRWE $100 \mathrm{mg} / \mathrm{kg}$, however, this is less than piracetam. TL is calculated in RDW test, there is significant increase in TL in control group from day $1(p<0.0001)$ to day 10 $(p<0.0001)$. However, TL decreased significantly in all treated groups from day $1(p<0.0001)$ to day $10(p<0.0001)$ as compared to control group. Piracetam is more effective than both doses of HRWE, whereas, effect of HRWE is dose dependent (Figure 3).

\subsection{Effect of HRWE on biochemical parameters and histopath- ological studies}

In biochemical estimations, control group animals showed significant increase in AChE levels $(p<0.0001)$, LPO levels $(p<0.0001)$, and NO levels $(p<0.0001)$. Similarly, these animals showed significant decrease in GSH levels $(p<0.0001)$ and SOD levels $(p<0.0001)$. Piracetam treated animals showed significant decrease in AChE levels $(p<0.0001)$, LPO levels $(p<0.0001)$, NO levels $(p<0.0001)$ and significant increase in GSH levels $(p<0.0001)$ and SOD levels $(p<0.0001)$ as compared to control group. HRWE treatment showed dose dependent effect. Lower dose of HRWE, i.e., $100 \mathrm{mg} / \mathrm{kg}$ showed significant decrease in AChE levels $(p<0.01)$, LPO level $(p<0.001)$ and NO levels $(p<0.05)$ as compared to control group. Whereas, higher dose of HRWE, i.e., $200 \mathrm{mg} / \mathrm{kg}$ showed significant decrease in AChE levels $(p<0.0001)$, LPO levels $(p<0.0001)$, NO levels $(p<0.0001)$ and significant increase in GSH levels $(p<0.05)$ and SOD levels $(\mathrm{p}<0.0001)$ as compared to control group. However, effect of HRWE is less than piracetam (Table 2). In histopathological studies, control group animals showed apoptotic neurons in cerebrum, piracetam treated animals showed normal morphology of cerebrum. HRWE $100 \mathrm{mg} / \mathrm{kg}$ and $200 \mathrm{mg} / \mathrm{kg}$ showed normal morphology of cerebellum without any signs of toxicity (Figure 4).

Table 2: Determination of AChE activity, malondialdehyde (MDA/TBARS), GSH, SOD and NO levels in the brain tissue of mice

\begin{tabular}{|c|c|c|c|c|c|}
\hline Treatment & $\begin{array}{c}\text { AChE }(\mu M \text { of } \\
\text { acetylthiocholine } \\
\text { hydrolyzed } / \mathrm{min} / \mathrm{mg} \\
\text { of tissue) }\end{array}$ & $\begin{array}{c}\text { LPO } \\
\text { (Nanomole of } \\
\text { MDA/mg of } \\
\text { protein) }\end{array}$ & $\begin{array}{c}\text { GSH } \\
\text { (nanomole } / \mathrm{mg} \\
\text { of protein) }\end{array}$ & $\begin{array}{c}\text { SOD } \\
\text { (SOD activity } \\
\text { (U/mg protein) }\end{array}$ & NO \\
\hline Normal & $1.1 \pm 0.071 * * * *$ & $64 \pm 0.94 * * * *$ & $19 \pm 1.1 * * * *$ & $3.3 \pm 0.055 * * * *$ & $90 \pm 1.512 * * * *$ \\
\hline Control & $3.0 \pm 0.234$ & $122 \pm 1.64$ & $8.9 \pm 0.81$ & $2 \pm 0.114$ & $128 \pm 2.335$ \\
\hline Piracetam $100 \mathrm{mg} / \mathrm{kg}$ & $1.1 \pm 0.181 * * * *$ & $73 \pm 2.82 * * * *$ & $16 \pm 1.7 * * * *$ & $3.2 \pm 0.026 * * * *$ & $93 \pm 1.347 * * * *$ \\
\hline HRWE $100 \mathrm{mg} / \mathrm{kg}$ & $2.0 \pm 0.152 * *$ & $95 \pm 3.27 * * *$ & $11 \pm 1.1^{\mathrm{ns}}$ & $2.2 \pm 0.045^{\mathrm{ns}}$ & $118 \pm 3.118^{*}$ \\
\hline HRWE $200 \mathrm{mg} / \mathrm{kg}$ & $1.5 \pm 0.172 * * * *$ & $86 \pm 8.014 * * * *$ & $13 \pm 0.63 *$ & $2.5 \pm 0.036^{* * * *}$ & $106 \pm 1.427 * * * *$ \\
\hline
\end{tabular}

All values are expressed as mean $\pm \mathrm{SEM}$, and tested by One-way ANOVA followed by Dunnett's multiple comparison test, $\mathrm{n}=5, *=p<0.05 ; * *=$ $p<0.01 ; * * *=p<0.001 ; * * * *=p<0.0001$ and $\mathrm{ns}=$ non-significant as compared to control group.

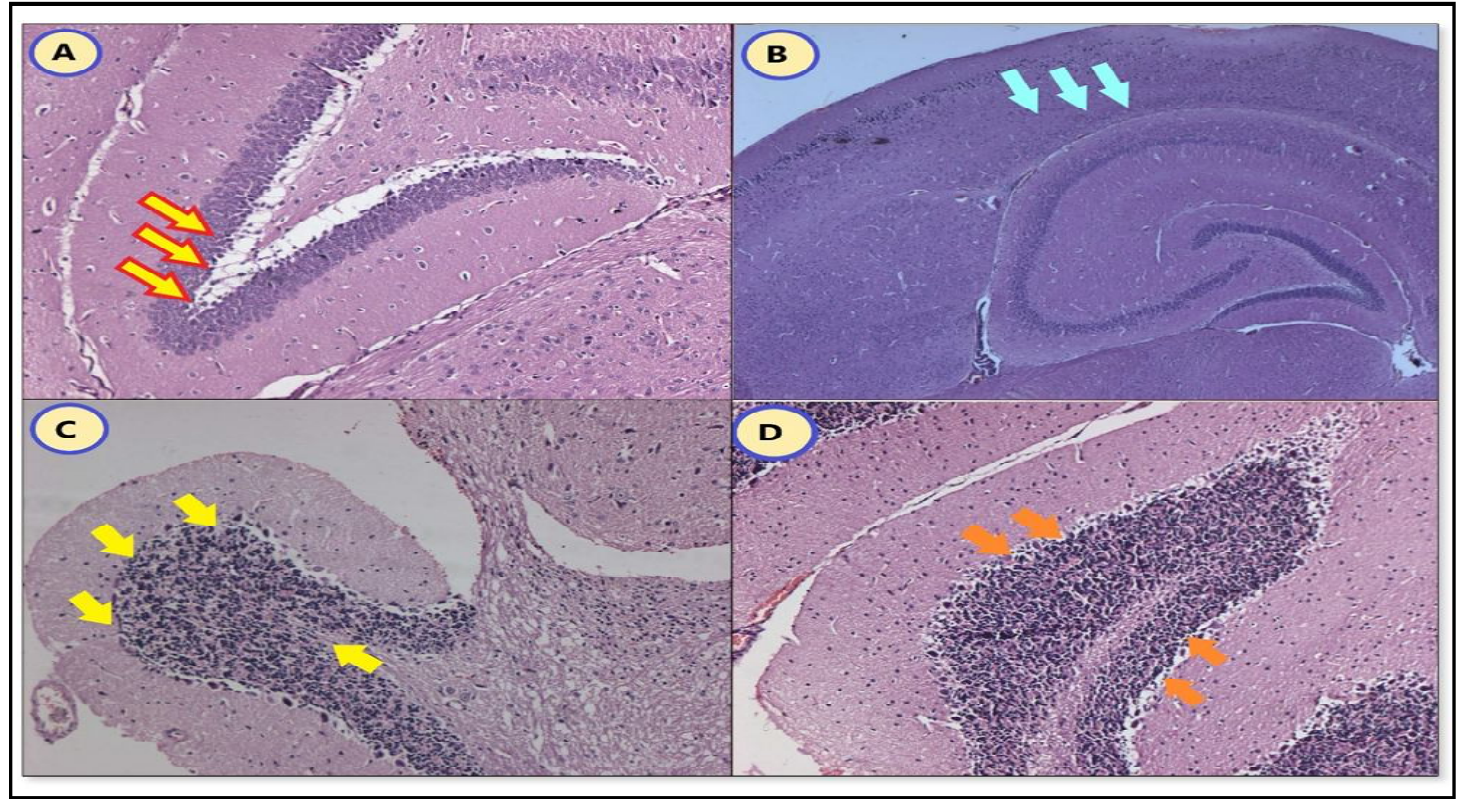

Figure 4: Effect of RSWE on mice brain. A: Control group: yellow arrow marks with red border indicates location of apoptotic neurons in cerebrum of phenytoin challenged mice. B: Arrow marks indicate normal morphology of cerebral cortex of Group II animals. C: Morphology of neurons is normal in cerebellum of HRWE $100 \mathrm{mg} / \mathrm{kg}$ treated group. D: Arrow marks represent normal cerebellum without any signs of toxicity. 


\section{Discussion}

Free radicals have an impact on health of human beings. Similarly, oxygen in few forms (reactive oxygen species) have very harmful effects on human body. Free radicals and reactive oxygen species are produced in human body either by normal metabolic process or by exposure to industrial chemicals, smoking, and X-rays, etc. (Lobo et $a l ., 2010)$. These are to be detoxified necessarily for cellular survival (Gill et al., 2011). They are effectively neutralized by synthetic antioxidants, viz., butylated hydroxytoluene and propyl gallate, etc., but their regular use is reported with severe side effects (Xiu-Qin et $a l ., 2009)$. In this context, it is mandatory to search for new and safer antioxidants. Plants are good source of regimen for many severe diseases (Imad Uddin and Veeresh, 2020). HRWE is reported to possess many important phytoconstituents like flavonoids, carbohydrates, glycosides, steroids, tannins, phenols, proteins, and triterpenoids (Ghaffar et al., 2012; Rajesh et al., 2011). Total phenolic content and total flavonoid content of leaves of HRWE was found to be $62.4 \%$ (mg/g catechol equivalent) and $73.2 \%(\mathrm{mg} / \mathrm{g}$ quercetin equivalent), respectively. These are majorly responsible for antioxidant activity. Many studies reported similar results, that these phytoconstituents are responsible for antioxidant effects of HRWE leaves (Rengarajan et al., 2015). In this study, antioxidant activity of leaves of HRWE can be extrapolated to presence of these phytoconstituents. Hence, establishment of antioxidant activity directs the study to screen cognitive improvement effect of leaves of HRWE.

A commonly used antiepileptic drug, phenytoin at a dose of $50 \mathrm{mg} /$ $\mathrm{kg}$ reported to impair cognitive abilities (Mondadori and Classen, 1984). So, it is given to all groups except normal to induce cognitive impairment. To screen protective effect of HRWE, various behavioral models are used. Retention and spatial memory are evaluated by using a very common model of MWM test. This is measured in terms of escape latency. Control group animals showed decrease in ability to reach central platform, indicated by increase in EL, this denotes impaired spatial and retention memory. These results are in accordance with study conducted by Churchill et al. (2003), in which phenytoin induced memory impairment is evaluated on MWM test. In piracetam, and HRWE $200 \mathrm{mg} / \mathrm{kg}$ treated groups, there is significant decrease in EL, indicating restoration of memory. This effect is not observed with HRWE $100 \mathrm{mg} / \mathrm{kg}$. Similar restoration of learning and memory in water maze test is also reported with ethanolic extract of Cressa cretica (Khare et al., 2014). Kumar et al. (2007), reported the EPM test for screening cognitive abilities. TL represented as inflexion ratio is recorded in EPM test. It is a measure of spatial memory. Control group animals showed decrease in IR representing memory loss. This ratio is increased in HRWE groups, but change is not significant except on day 5 with HRWE $200 \mathrm{mg} / \mathrm{kg}$. Increase in IR is directly related to memory improvement. Similar results are reported with Orthosiphon stamineus (Retinasamy et al, 2019). CPC test is a very common method to screen cognitive abilities. Conditioned and unconditional stimuli are used to assess long-term memory functions of animals. RT is recorded in this test. Increase in RT in control group animals represents loss of memory. Decrease in RT indicates memory improvement in piracetam, and HRWE $200 \mathrm{mg} / \mathrm{kg}$ treated groups. This indicates that HRWE $100 \mathrm{mg} / \mathrm{kg}$ is not sufficient to restore memory function in this test. Similar results are reported by Ramarao et al. (2018), with water extract of Tridax procumbens. Non-spatial long-term memory is assessed by NOR test. RI is recorded for all animals. Decrease in RI indicates disturbed memory in Group II animals, on reverse increase in RI indicates retention of memory. This memory retention effect is shown all the animals treated with piracetam, but in HRWE treated groups, this effect is reported only on $10^{\text {th }}$ day with both doses. Similar results are reported with respect to NOR by Hashimoto et al. (2020).

Phenytoin a part form inducing learning and memory impairment, it is also reported with muscle relaxation effect on chronic use. So, fall off time in RTR test is used to measure this effect. Decrease in FOT in control group animals showed muscle relaxation. Significant increase in this FOT in all treated groups indicates normal functioning of muscles. Tippu et al. (2018) reported similar effects in swiss albino mice. RDW test is used to record TL of animals. It is used to assess spatial memory of mice. Increase in TL in control group animals show disturbed memory, which is restored in all the treated groups indicated by decrease in TL.

Maurer and Williams (2017) reported the importance of cholinergic system in normal life. Degradation of these neurons severely impairs memory and learning abilities. One important cause for decrease in acetylcholine levels is the increase in activity of AChE in brain (Silveyra et al., 2012). Phenytoin is reported to decrease acetylcholine levels in different parts of brain of animals (Agarwal and Bhargava, 1964). In our study, brain AChE levels are increased in control group animals representing deleterious effects on memory and learning process. This level is restored on treatment with piracetam and both doses of HRWE, indicating their potential effect in restoring learning and memory process by improving cholinergic system of brain. Our results are consistent with study conducted by Khan et al. (2012). LPO is measured in terms of TBARS, increased in levels of TBARS indicate inhibition of metabolic enzymes (Nobre-Junior et al., 2009; Matsunami et al., 2010; Tamanna et al., 2020). In this study, phenytoin challenged mice showed increase in levels of TBARS indicating enzymatic damage to host cells. Decrease in TBARS level indicate protection provided to metabolic enzymes by piracetam and HRWE. NO and its derivatives are the indicators of oxidative stress, leading to neurological disturbances (Chung and David, 2010). Increase in levels of NO in control group animals represents cognitive disabilities. This level is decreased in all treatment groups indicating their protection against NO stress and retaining cognitive functions.

SOD is well known to convert harmful superoxide in to hydrogen peroxide and oxygen molecule (Buettner, 2011). Whereas, GSH acts by converting hydrogen peroxide into water (Lubos et al., 2011). Decrease in their level in group II animals can be extrapolated to their neurological related problems like cognitive impairment. However, increase in their levels in treated animals is extrapolated to cognitive improvement. HRWE $100 \mathrm{mg} / \mathrm{kg}$ has not showed significant effect on these enzyme levels. Whereas, HRWE $200 \mathrm{mg} / \mathrm{kg}$ is more effective in restoring SOD levels than restoring GSH levels. In histopathological assessment, control group animals showed apoptosis of neurons in cerebrum, this neurotoxicity induced by phenytoin is in consistent with study conducted by Ohmori et al. (1992). Normal morphology of cerebral cortex and cerebellum in treated group animals indicate their neuroprotection effect, which can be extrapolated to restoration of behavioral and biochemical parameters in these groups.

\section{Conclusion}

Current study is clearly justifying the neuroprotective effect of aqueous extract of $H$. rosa-sinensis. Effect of HRWE was dose dependent throughout the study. Animals treated with HRWE showed 
normal behavior in all the screening models, indicating their cognitive improvement effects. These effects are well supported by restoration of biochemical enzymes to normal levels in brain homogenate. Normal histoarchitecture of cerebrum and cerebellum of treated animals also supports the results obtained in in vitro and in vivo studies. Therefore, neuroprotective effect produced by HRWE can be extrapolated to their antioxidant action. Based on these considerations, current study presents an idea to conduct, further research, and also to explore molecular level mechanism involved in neuroprotective effect.

\section{Conflicts of interest}

The authors declare no conflicts of interest relevant to this article.

\section{References}

Abdulrahman M. Alshahrani. (2019). Appraisal of a neuroprotective consequence of Curcuma zedoaria Roxb. rhizomes on memory malfunction in oxidative tension convinced C6 glioma cells of rats. Ann. Phytomed., 8(2):105-107.

Abubucker Peer Mohideen. (2021). In silico identification of novel immune stimulating phytochemicals with acetylcholinesterase inhibition activity from Piper betle L. and Vitex negundo L. for the treatment of Alzheimer's disease (AD): Ann. Phytomed., 10(1):86-95. http:/ /dx.doi.org/10.21276/ap.2021.10.1.9

Afiune, L.A.; Leal-Silva, T.; Sinzato, Y.K.; Moraes-Souza, R.Q.; Soares, T.S.; Campos, K.E.; Fujiwara, R.T.; Herrera, E.; Damasceno, D.C. and Volpato, G.T. (2017). Beneficial effects of Hibiscus rosa-sinensis L. flower aqueous extract in pregnant rats with diabetes. PLoS One, 12(6):e0179785.

Agarwal, S.L. and Bhargava, V. (1964). Effect of drugs on brain acetylcholine level in rats. Indian J. Med. Res., 52:1179-1182.

Antunes, M. and Biala, G. (2012). The novel object recognition memory: Neurobiology, test procedure, and its modifications. Cognitive Processing, 13(2):93-110.

Appleyard, M.E. (1992). Secreted acetylcholinestrate: Non classical aspects of a classical enzyme. Trends Neurosci., 15:485-490.

Batool, Z; Sadir, S.; Liaquat, L.; Tabassum, S.; Madiha, S.; Rafiq, S.; Tariq, S.; Batool, T.S.; Saleem, S.; Naqvi, F.; Perveen, T. and Haider, S. (2016). Repeated administration of almonds increases brain acetylcholine levels and enhances memory function in healthy rats while attenuates memory deficits in animal model of amnesia. Brain Res Bull., 120:63-74.

Begum, Z; Younus, I.; Khan, H. and Ali, S.M. (2016). Ethanolic crude extract of roots of Hibiscus rosa sinensis ameliorates depression like behaviour in animal models. Advances in Biological Research, 10(3):132137.

Bhatti, M.Z.; Ali, A.; Ahmad, A.; Saeed, A. and Malik, S.A. (2015). Antioxidan and phytochemical analysis of Ranunculus arvensis L. extracts. BMC Research Notes, 8(1):1-8.

Braglia, L.; Bruna, S.; Lanteri, S.; Mercuri, A. and Portis, E. (2010). An AFLPbased assessment of the genetic diversity within Hibiscus rosasinensis and its place within the Hibiscus genus complex. Sci. Hortic. Amsterdam, 123(3):372-378.

Buettner, G.R. (2011). Superoxide dismutase in redox biology: The roles of superoxide and hydrogen peroxide. Anticancer Agent ME, 11(4), 341-346. https://doi.org/10.2174/187152011795677544

Churchill, J.D.; Fang, P.C.; Voss, S.E.; Besheer, J.; Herron, A.L. and Garraghty, P.E. (2003). Some antiepileptic compounds impair learning by rats in a Morris water maze. Integr. Physiol. Behav. Sci, 38(2):91-103. doi: 10.1007/BF02688828. PMID: 14527179.
Daud, D.; Arsad, N.F.M.; Ismail, A. and Tawang, A. (2016). Antipyretic action of Caulerpa lentillifera, Hibiscus rosa-sinensis, and Piper sarmentosum aqueous extract in mice. Asian Journal of Pharmaceutical and Clinical Research, 9(1):145-147.

Davies, P. and Maloney, A.J.F. (1976). Selective loss of central cholinergic neurons in Alzheimer's type disease. Lancet, 2:1403.

Dhingra, D. and Kumar, V. (2012). Memory-enhancing activity of palmatine in mice using elevated plus maze and morris water maze. Adv. Phar. Sc, pp:1-7.

Domaradzki, J. (2015). The impact of Huntington disease on family carers: A literature overview. Psychiatr. Pol., 49:931-944.

Ellman, G.L.; Courtney, K.D.; Andres, V.Jr. and Feather Stone, R.M. (1961). A new rapid colorimetric determination of acetylcholine esterase activity. Biochem Pharmacol., 7(2):88-95

Ennaceur, A. and Delacour, J. (1988). A new one-trial test for neurobiological studies of memory in rats. 1: behavioral data. Behav. Brain Res., 31(1):47-59. doi: 10.1016/0166-4328(88)90157-X

Ghaffar, F.R. and El-Elaimy, I.A. (2012). In vitro, antioxidant and scavenging activities of Hibiscus rosa-sinensis crude extract. Journal of Applied Pharmaceutical Science, 2(2):51.

Gill, S.S.; Khan, N.A.; Anjum, N.A. and Tuteja, N. (2011). "Amelioration of cadmium stress in crop plants by nutrients management: Morphological, physiological and biochemical aspects," in Plant Nutrition and Abiotic Stress Tolerance III, Plant Stress 5 (Special Issue 1), eds N. A. Anjum and F. Lopez-Lauri, (Ikenobe: Global Science Books Ltd., UK), 1-23.

Goldberg, K.H.; Yin,A.C.; Mupparapu,A.; Retzbach, E.P.; Goldberg, G.S. and Yang, C.F. (2017). Components in aqueous Hibiscus rosa-sinensis flower extract inhibit in vitro melanoma cell growth. Journal of Traditional and Complementary Medicine, 7(1):45-9.

Nobre-Junior, H.V.; Fonteles, M.M.D.F. and Freitas, R.M.D. (2009). Acute seizure activity promotes lipid peroxidation, increased nitrite levels and adaptive pathways against oxidative stress in the frontal cortex and striatum. Oxidative Medicine and Cellular Longevity, 2(3):130137.

Hanumakonda, A. and Maheshwaram, V. (2016). Neuroprotective activity of Hibiscus rosa-sinensis flowers in scopolamine induced cognitive decline rats. International Journal of Pharmacy Review and Research, 6(1):15-21.

Hashimoto, M.; Nakai, T.; Masutani, T.; Unno, K. and Akao, Y. (2020). Improvement of learning and memory in senescence-accelerated mice by s-allylcysteine in mature garlic extract. Nutrients, 12(6): 1834 .

Hazzard, W.R. and Halter, J.B. (2009). Hazzard's Geriatric Medicine and Gerontology. 6th ed. New York, NY: McGraw-Hill.

Hemarana, K.; Jeyashree, K.V.; Babu, M. and Kannan, M. (2014). Preliminary bioactive compounds screening and antibacterial activity of methanolic extract of Hibiscus rosa-sinensis against selected skin pathogens. Research Journal of Pharmaceutical, Biological and Chemical Sciences, 5(2):1210-1218.

Imaduddin, M.D.; Vandana, A.; Kavya, G. and Syed, Y.H. (2020). Systematic study on protective role of date palm (Phoenix dactylifera L.) on central nervous system disorders. Ann. Phytomed., 9(1):58-65.

Jadhav, V.M.; Thorat, R.M.; Kadam, V.J. and Sathe, N.S. (2009). Hibiscus rosasinensis Linn - "Rudrapuspa": A review. Journal of Pharmacy Research, 2(7):1168-1173. 
Jaiswal, A.K and Bhattacharya, S.K. (1992). Effect of Shilajit on memory, anxiety and brain monoamines in rats. Indian J. Pharmacol., 24;1217.

Chung, K.K.K. and David, K.K. (2010). Emerging roles of nitric oxide in neurodegeneration. Nitric Oxide, 22(4):290-295.

Kamila, S.; Madhav, N.S. and Sarkar, C.N. (2014). Pharmacological evaluation of transcranially applied lignocaine gel as a novel amnesic agent on rodents. Int., J. Pharm. Sci. Invent., 3(7):13-21.

Khalid, L.; Rizwani, G.H.; Sultana, V.; Zahid, H.; Khursheed, R. and Shareef, H. (2014). Antidepressant activity of ethanolic extract of Hibiscus rosa-sinensis Linn. Pak. J. Pharm. Sci., 27:1327-1331.

Khan, R.A.; Khan, M.R. and Sahreen, S. (2012). Brain antioxidant markers, cognitive performance and acetylcholinesterase activity of rats: efficiency of Sonchus asper. Behav. Brain. Funct., 8(1):1-7.

Khare, P.; Chaudhary, S.; Singh, L.; Yadav, G. and Verma, S. (2014). Evaluation of nootropic activity of Cressa cretica in scopolamine-induced memory impairment in mice. International Journal of Pharmacology and Toxicology, 2(2):24-29.

Khynriam, D. and Prasad, S.B. (2003). Changes in endogenous tissue glutathione level in relation to murine ascites tumor growth and the anticancer activity of cisplatin. Braz. J. Med. Biol. Res, 36:5363.

Klein, S.M.; Cohen, G. and Cederbaum, A.I. (1981). Production of formaldehyde during metabolism of dimethyl sulphoxide by hydroxyl radical generating system. Biochemistry, 20:6006-6012.

Kumar, V.; Mahdi, F.; Khanna,A.K.; Singh, R.; Chander, R.; Saxena, J.K.; Mahdi, A.A. and Singh, R.K. (2013). Antidyslipidemic and antioxidant activities of Hibiscus rosa sinensis root extract in alloxan induced diabetic rats. Indian Journal of Clinical Biochemistry, 28(1):46-50.

Kumar, A.; Seghal, N.; Naidu, P.S.; Padi, S.S. and Goyal, R. (2007). Colchicinesinduced neurotoxicity as an animal model of sporadic dementia of Alzheimer's type. Pharmacol. Rep., 59:274-283.

Kumar, S. and Minshu, P. (2016). Memory enhancing activity of polyherbal formulation medhyarasayana in scopolamine induced amnesia in rat. IJRPC, 6(3):556-567.

Kuribara, H.; Higuchi, Y. and Tadokoro. S. (1977). Effects of central depressants on rotarod and traction performances in mice. Japan. J. Pharmacol., 27(1):117-126.

Lauterbach, E.C.; Victoro, J.; Coburn, K.L.; Shillcutt,S.D.; Doonan, S.M. and Mendez, M.F. (2010). Psychopharmacological neuroprotection in neurodegenerative disease: Assessing the preclinical data. J. Neuropsychiatry Clin. Neurosci, 22:8-18.

Lobo, V.; Patil, A.; Phatak, A. and Chandra, N. (2010). Free radicals, antioxidants and functional foods: Impact on human health. Pharmacognosy Reviews, 4(8): 118.

Lubos, E., Loscalzo, J., and Handy, D.E. (2011). Glutathione peroxidase-1 in health and disease: From molecular mechanisms to therapeutic opportunities. Antioxid. Redox. Sign, 15(7):1957-1997. https:// doi.org/10.1089/ars.2010.3586

Mangialasche, F.; Solomon, A.; Winblad, B.; Mecocci, P. and Kivipelto, M. (2010) Alzheimer's disease: Clinical trials and drug development. Lancet Neurol., 9:702-716.

Masaki, H.S.; Sakaki, S.; Atsumi, T. and Sakurai, H. (1995). Active oxygen scavenging activity of plant extracts. Biol. Pharm. Bull., 18:162166. https://doi.org/10.1248/bpb.18.162 PMID: 7735233

Matsunami, T.; Sato, Y.; Sato, T. and Yukawa, M. (2010). Antioxidant status and lipid peroxidation in diabetic rats under hyperbaric oxygen exposure. Physiol. Res., 59(1): 97-104
Maurer, S.V. and Williams, C.L. (2017). The cholinergic system modulates memory and hippocampal plasticity via its interactions with nonneuronal cells. Front immunol., 8:1489. https://doi.org/10.3389/ fimmu.2017.01489

Imad Uddin, M.D. and Veeresh, B. (2020). Systematic review on screening the role of chemosensitizer or synergistic drug and doxorubicin as dual drug loaded nanoparticle in overcoming multidrug resistant breast cancer. Ann. Phytomed., 9(2):113-124. http://dx.doi.org/10.21276/ ap.2020.9.2.9

Misra, H. and Fridovich, I. (1972). The role of superoxide anion in the autoxidation of epinephrine and a sample assay for superoxide dismutase. J. Biol. Chem., 247:3170-3175.

Mondadori. C. and Classen, W. (1984). The effects of various antiepileptic drugs on E-shock induced amnesia in mice: Dissociability of effects on convulsions and effects on memory. Acta Neurol Scand., 69(S99): 125-129.

Moqbel, F.; Naik, P.R.; Najma, H.M. and Selvaraj, S. (2011). Antidiabetic properties of Hibiscus rosa-sinensis L. leaf extract fractions on nonobese diabetic (NOD) mouse. Indian. J. Exp. Biol., 49(1):24-29.

Moran, T.H.; Capone, G.T.; Knipp, S.; Davisson, M.T.; Reeves, R.H. and Gearhart, J.D. (2002). The effects of piracetam on cognitive performance in a mouse model of Down's syndrome. Physiol. Behav., 77(2-3):403409 .

Morris, R.G.M. (1981). Spatial localization does not require the presence of local cues. Learning and Motivation, 2(2):239-260.

Nayak, D.; Ashe, S.; Rauta, P.R. and Nayak, B. (2014). Biosynthesis, characterisation and antimicrobial activity of silver nanoparticles using Hibiscus rosa-sinensis petals extracts. IET Nanobiotechnol., 9:288-293. https://doi.org/10.1049/iet-nbt.2014.0047.

Ohmori, H.; Kobayashi, T. and Yasuda, M. (1992). Neurotoxicity of phenytoin administered to newborn mice on developing cerebellum. Neurotoxicol. Teratol., 14(3):159-65. doi: 10.1016/08920362(92)90011-X. Erratum in: Neurotoxicol. Teratol, 1992;14(5):373. PMID: 1635536.

Okhawa, H.; Ohishi, N. and Yagi, K. (1979). Assay of lipid peroxides in animal tissues by thiobarbituraic acid reaction. Anal. Biochem., 95:351358.

Polinsky, R.J. (1998). Clinical pharmacology of rivastigmine: A newgeneration acetylcholinesterase inhibitor for the treatment of Alzheimer's disease. Clin. Ther., 20:634-647.

Raduan,S.Z; Abdul Aziz, M.W.; Roslida, A.H.; Zakaria, Z.A.; Zuraini, A. and Hakim, M.N. (2013). Anti-inflammatory effects of Hibiscus rosa-sinensis $L$. and Hibiscus rosa-sinensis var. alba ethanol extracts. Int. J. Pharm. Pharm. Sci., 5(4):754-762.

Rajesh, M.; Sreenivas, S.A.; Sakarkar, D.M. and Choudhury, A. (2011). Radical scavenging and antioxidant activity of Hibiscus rosa-sinensis extract. Afr. J. Pharm. Pharmaco., 5(17):2027-2034.

Ramrao, M.R.; Burande, M.D.; Jangme, C.M. and Ladde, S.S. (2018). Evaluation of nootropic effects of aqueous extract of Tridax procumbens linn on cognitive functions in mice. RJLBPCS, 4(6):242-251.

Rengarajan, S.U.; Melanathuru, V.I. and Munuswamy, D.E. (2015). Comparative studies of antioxidant activity from the petals of selected Indian medicinal plants. Int. J. Pharmacy and Pharmaceutical Sciences, 7(6):29-34.

Retinasamy, T.; Shaikh, M.F.; Kumari, Y. and Othman, I. (2019). Ethanolic extract of Orthosiphon stamineus improves memory in scopolamineinduced amnesia model. Front. Pharmacol., 10:1216. 
Rogers, S.L.; Farlow, M.R.; Doody, R.S.; Mohs, R. and Friedho, L.T. (1998). A 24 week, double-blind, placebo-controlled trial of donepezil in patients with Alzheimer's disease. Donepezil Study Group Neurology, 50:136145 .

Ruch, R.J.; Cheng, S.J. and Klaunig, J.E. (1989). Prevention of cytotoxicity and inhibition of intercellular communication by antioxidant catechins isolated from Chinese green tea. Carcinogenesis, 10:10031008

Sedlak, J. and Lindsay, R.H. (1968). Estimation of total, protein-bound, and non-protein sulfhydryl groups in tissue with Ellman's reagent. Anal. Biochem., 25:192-205.

Senathirajah, T.; Rasalingam, S. and Ganeshalingam, S. (2017). Extraction of the cyanidin-3-sophoroside from Hibiscus rosa-sinensis: An efficient natural indicator over a wide range of acid-base titrations. Journal of Natural Product and Plant Resources, 7(3):1-7.

Silveyra, M.X.; García-Ayllón, M.S.; de Barreda, E.G.; Small, D.H.; Martínez, S.; Avila, J. and Saez-Valero, J. (2012). Altered expression of brain acetylcholinesterase in FTDP-17 human tau transgenic mice. Neurobiol. Ageing, 33(3):624.e23-34. doi: 10.1016/ j.neurobiolaging.2011.03.006

Sobhy, E.A.; Abd Elaleem, K.G. and Abd Elaleem, H.G. (2017). Potentia antibacterial activity of Hibiscus rosa-sinensis Linn. flowers extracts. International Journal of Current Microbiology and Applied Sciences, 6(4):1066-1072.

Soni, D. and Gupta, A. (2011). An evaluation of antipyretic and analgesic potentials of aqueous root extract of Hibiscus rosa-sinensis Linn. (Malvacae). International Journal of Research in Phytochemistry and Pharmacology, 1(3):184-186.
Sudha, S.; Lakshmana, M.K. and Pradhan, N. (1995). Chronic phenytoin induced impairment of learning and memory with associated changes in brain acetylcholine esterase activity and monoamine levels. Pharmacol. Biochem. Be., 52(1):119-24.

Talih, F. and Ajaltouni, J. (2015). Probable nootropic induced psychiatric adverse effects: A series of four cases. Innovations in Clinical Neuroscience, 12(11-12):21.

Tamanna, M.; Madan, V.K. and Ram Prakash. (2020). Herbs that heal: Floristic boon to the natural healthcare system. Ann. Phytomed., 9(2):1-9. http://dx.doi.org/10.21276/ap.2020.9.2.00.

Tippu, A.H.; Imaduddin, M.D.; Chanabasappa, K.B. and Pradeep, R. (2018). Evaluation of neuroprotective potential of some newly synthesized benzopyran-2-one derivatives in swiss albino mice. Indian J. Pharm. Educ., 52(4):S326-S332.

Vohora, D.; Pal, S.N. and Pillai, K.K. (2000). Protection from phenytoin-induced cognitive deficit by Bacopa monniera, a reputed Indian nootropic plant. J. Ethnopharmacol., 71:383-390. [PubMed: 10940574]

Wurtman, R.J.; Magil, S.G. and Reinstein, D.K. (1981). Piracetam diminishes hippocampal acetylcholine levels in rats. Life Sci., 28:1091-1093.

XiuQin, L.; Chao, J.; Yan Yan, S.; Min Li, Y. and Xiao Gang, C. (2009). Analysis of synthetic antioxidants and preservatives in edible vegetable oil by HPLC/TOF-MS. Food Chem., 113:692-700. doi: 10.1016/ j.foodchem.2008.07.072.

Zaki, L.H.; Mohamed, S.M.; Bashandy, S.A.E.; Morsy, F.A.; Tawfik, K.M. and Shahat, A.A. (2017). Hypoglycemic and antioxidant effects of Hibiscus rosasinensis L. leaves extract on liver and kidney damage in streptozotocin induced diabetic rats. Afr. J. Pharm. Pharmaco., 11(13): 161-169.

Syed Ahmedullah Hussaini Quadri, Maya Sharma, Khaja Pasha and Javed Akhtar Ansari. (2021). Screening the 